RIMÓCZI-HAMAR MÁRTA*

\title{
HORATIUS ÉS BABITS AZ ÉVSZAKOKRÓL
}

\author{
(VIVALDI „A NÉGY ÉVSZAK” HALLGATÁSA KÖZBEN)
}

BORZSÁK ISTVÁN AKADÉMIKUS PROFESSZOR ÚRNAK SZÜLETÉSNAPI KÖSZÖNTÉSÜL. 2000. DECEMBER 24.

Mind Horatius ódája, mind Babits verse valamiféle „életösszegezése” a két költő alkotólétének. A versek hangulata látszólag lemondó, valójában azonban erőteljes életigenlés sugárzik felénk a nagy költői láttató erejú versekből. Ezt a belülrôl jövő erôt és hitet az öröklétben erősíti Vivaldi hatásos zenéje, amelyből szintén az örök körforgás biztosította halhatatlanság érzése szól hozzánk, a zene és költészet nyelvén. Két évezredet nyújt át az „öröklétből” Horatius záró ódakötetének középső, 7. carmenja, Babits még a közelmúltból szól, de a versek összecsengése, az alkotó lét mindkettőjüknek biztosítja a halhatatlanságot és velük együtt mindazoknak, akik a kozmosz tevékeny embereiként annak hibátlan törvényeit követve élik életüket úgy, hogy a ,percnyi léthez” a „végetlen érzetének” madáchi bizonyosságát is hozzácsatolják.

Hangfelvételi ritkaságként Vivaldi „A négy évszak” címú concertóját korabeli hangszereléssel hallgathatjuk. Az egyes tételek között Vivaldi évszak-szonettjei öszszehasonlításra késztetnek egyrészt Horatius híres IV. 7. carmenjével, másrészt Babits „Ősz és tavasz között” címú költeményével. A zeneszerző verseivel hangsúlyozni kívánja, hogy az évszakok szépségeit nem csak dallamokkal, hanem láttató erejú verssorokkal is képes még átélhetőbbé tenni. A mindenkori elmúlásban benne lüktet az állandó újrakezdés öröme. Némává halkuló pianissimókból törnek elő a borzongatóan dübörgő, de frissítő fortissimók. A versek és a zenemú ütemei festôi erôvel közvetítik a zeneszerző költő érzéseit az évszakok változásáról. Ennek az élménynek a hatása megjeleníti előttünk Horatius és Babits évszakokat idéző verseit is. Vivaldi hallgatása távlatokat nyit és zár, megismétli az újrakezdés és elmúlás motívumait. Újra és újra! Az emberi élet valamennyi évszakát megélni csakis kiválasztottaknak adatik meg. Törhetetlenné válnak ekkorra a töréseket nem nélkülözó életpályák is.

* E tanulmány elkészítésében részt vettek a „Horatius olvasásakor” c. speciális kollégium hallgatói: Agrillo Vivienne, Bányay Krisztina, Bíró Zsófia, Boros Karina Agnes, Chikány Erzsébet, Farkas Gabriella, Fehér Judit, Friedrich Eszter, Futász Réka, Galambos András, Horváth Attila, Horváth Áron, Koncz Ádám, Madlena Zsolt, Manhercz Orsolya Ágnes, Máté Katalin, Naményi Krisztina, Paraizs Veronika, Pál Gergely, Perényi Katalin, Puskás Nóra Mónika, Prakfalvy Réka, Szabó Andrea, Szalay Gabriella, Takács Anett, Timkovics Dorottya, Vajda Henrik, Vörös Mercédesz. 
Borzsák István professzor élete az emberi lét valamennyi évszakát átöleli. Generációk mestere, tanára mind a mai napig. Megadatott Neki, hogy a teremtô lét megélésével teljesedjék be, váljék egésszé emberi és tudósi léte. Írásunkkal szeretnénk hitelesíteni, hogy a „tél”, a „csendes, tiszta tél” az alkotó évszakoknak — talán - a legszebbje. Mind az évszakok télideje, mind az emberélet tele teljességet nyújt és ugyanazt kéri. A körforgás, a kör az öröklét jelképe. Ez az életkör a XX. század elejétől forog át a XXI. századba. A sejtett öröklét hogyan bontakozik ki e két versből, amelyek látszólag az elmúlásról szólnak? Ez az általánosan elfogadott vélemény, pedig e versek nem kelthetik ezt az érzést. Ellenkezőleg! A versek körforgásleírása kizárja a mulandóságot. A természet örök körforgásában - amely tagadhatatlan az ember is benne foglaltatik. Ha pedig a természet örök, akkor alkotóelemei — így az ember is - részesei az örökkévalóságnak. Babits is ezt érzi és érzékeltetni is akarja e különös versében.

A maga módján minden teremtett lény halhatatlan. Az alkotók örökléte ezen belül egészen különös gyökerú. E gyökereknek teremtő érzelmektől kell dúsaknak lenniük, hogy táplálhassák az alkotókon keresztül az öröklétú múveket. Az értelem örök kételyeit csak az érzelmek tudják feloldani. E kettő egysége a halhatatlanság hordozója. Az ősi és elsődleges táplálóerő az érzelem. Minden alkotásnál felfedezhető, mikor rezdült meg az alkotó érzelemvilága, amely lendületbe hozta a mú születését. Ez az élmény - a „csodaszép” — érint meg bennünket Babits halhatatlan soraiban:

„Nem az énekes szüli a dalt: a dal szüli énekesét.

Lobbanj föl, új dal, te mindenható!

Szülj engem újra, te csodaszép!"

(Mint forró csontok a máglyán)

Babits „esdekli” az újjászületést. Majd hirtelen a magáramaradottság kétségbeesésével folytatja:

„Barátaim elhagytak engem:

egyedül maradtam már."

(Mint forró csontok a máglyán)

Szinte szó szerint olvashatjuk e reménytelenséget árasztó gondolatokat az „Ősz és tavasz között" címú versében is:

„Barátaim egyenkint elhagytak, akikkel jót tettem, megtagadtak: akiket szerettem, nem szeretnek, ...

Ami betût ágam írt a porba, A tavasz sárvize elsodorja." 
Már a vers kezdő sora is lemondó. Úgy tûnik, a többi sem vidám:

„Elzengett az ôszi boros ének.”

(1. versszak)

„Leesett a hó a silány földre, talán csak hogy csúfságát befödje."

(3. versszak)

„Már az év, mint homokóra, fordul: elfogy az ó, most kezd fogyni az új, s mint unt homokját a homokóra, hagyja gondját az ó év az újra."

„Olvad a hó, tavasz akar lenni.

...

Pehely vagyok, olvadok a hóval,

Mely elfoly, mint a könny, elszáll, mint a sóhaj.

Mire a madarak visszatérnek,

Szikkad a föld, híre sincs a télnek...”

(7. versszak)

Csupasz, ôszi szôlótő, a tavasz sárvize ... mind lehangolónak tûnik, de összességében reményvesztett-e ez a vers? Nem lehet kétségünk a vers olvastán, hogy Babits jól ismerte Horatius Torquatus-ódáját (Carm. IV. 7). Az alábbiakban ezt a feltevésünket szeretnénk bizonyítani, bár bizonyításra aligha szorul, legfeljebb a vers új értelmezésérôl lehet szó.

Saját életérzésének megfelelően Babitsnál az ôsz (őszutó) a „nyitó” évszak a tavasz helyett. Ennek ellenére nála éppúgy érezzük az öröklét-élmény hangulatát, mint Horatiusnál.

Babits

1. versszak: ôsz van

3. versszak: tél van

7. versszak összecseng
Horatius

1-2. versszak: tavasz van 3. versszak: nincs évszak! Felszólítás hangzik: „halhatatlanságot $\mathrm{Ne}$ remélj!” (ti. te halandó!)

4. versszak

Olvad a hó, tavasz akar lenni.” A tavasz, nyár, ősz, tél szinte követhetetlenül gyors, festôien szép változásának leírása 
Babitsnál a tavasz csak a 7. versszakban jelenik meg, Horatiusnál pedig már a vers kezdetén látjuk, észleljük, éljük a tavasz érkeztét.

$$
\begin{array}{rr}
\text { "Olvad a hó, tavasz akar lenni." } & \text { Diffugere nives... } \\
\text { (7. versszak) } & \text { (1. versszak) }
\end{array}
$$

Figyelemre méltó az igeidók használata: Horatiusnál múlt, Babitsnál jelen. A két ige — Babitsnál „elzengett” (az ének), Horatiusnál „elolvadt” (a hó) - teljesen más érzelmi töltésú. Bizakodás az egyikben, lemondás a másikban. Kérdés, melyik érzés kerekedik felül. Gondolkodhatunk, Babits két- vagy egyévszakú költő? Ha „télévszakú” csak, akkor pesszimizmus hatja-e át? Lesz halhatatlanság „télvíz” idején, a „sárvizes” tavaszelőn? Igaz, halk bizonyosságú, de mégis optimizmus rezeg át a verssorokon:

„Mire a madarak visszatérnek, szikkad a föld, híre sincs a télnek...

Lesz halhatatlanság! Megjósolja Babits magának:

„Csak az én telem nem ily mulandó. Csak az én halálom nem halandó.”

Ide kívánkozik Babits prózai vallomása is arról a „mulandóságról”, amely mégsem mulandó. Foglalkoztatja ôt a halhatatlanság nagy talánya a barátság érzésének maradandóságával együtt. A lelkekból való egymás közötti „,részesedés” vagy „lélekfelezés" az élet nélkülözhetetlen szépségéhez tartozik. Nem mellózhetjük gyönyörú gondolatait Shelley és Keats barátságáról. Elsiratja ô is Keatset Shelleyvel együtt. Keats fiatalon repült „múvészetének égmagasára”. Shelley ekkor ír siratót barátja emlékére Adonais címmel. „Shelley a költőt gyászolja ... de a végén mégsem a halálnak, hanem a halhatatlan életnek himnusza lesz ez ... A halhatatlan élet csakugyan megy tovább s nem törődik a halállal". ${ }^{1}$ Ennél szebb és tömörebb költôii vallomás nehezen képzelhetô el. Ihletett prózában él az élet.

Nem mellőzhetjük Babits és Horatius elgondolkodtató biográfiai koincidenciáját sem. Horatius 57. éve küszöbén, Babits 58. életéve betöltése után távozik az életből. Pontosan hatvanadik éve, 1941-ben, szólította el e földi világból az ég. $\mathrm{Az}$ emberi lét évszakait ók nem érhették meg, de verseikben magukkal együtt itt hagyták azokat, festőien, elevenen, sugárzóan. Ók pedig mindketten korán, múvészetük „égmagasát” elérve távoztak a halhatatlanok közé, ahol Babits halála „nem 
halandó”, s a „tele” sem mulandó. A babitsi sorok horatiusi hangulatára Borzsák professzor már 1975-ben felhívta a figyelmet Horatius ódáihoz írott kommentárjában. ${ }^{2} \mathrm{Ez}$ a helymegjelölés egyben utalás Horatius magyarországi utóéletének egyik jeles helyére. E szép összecsengésre figyelve kíséreljük meg a két vers összehasonlító elemzését.

Horatiusnál megvan az évszakok körforgása, de látszólag nincs remény a halhatatlanságra.

\section{Frigora mitescunt Zephyris, ver proterit aestas interitura, simul pomifer autumnus fruges effuderit, et mox bruma recurrit iners.}

\section{(3. versszak)}

„A hideg »megenyhül« a tavaszi szelektól ..., a diadalmaskodó tavaszt mint valami ellenállhatatlan hódító »tiporja el« a nyár, ..., de a nyár is »elmúlásra van rendelve«, jóságosabb, de feltartóztathatatlan utód a »pomifer « jelzôvel ékes ôsz is ..., amely mintegy bőségszarujából »árasztja « ajándékait, a gyümölcsöket.”3 A versszak végén újra tél van: „és máris fut - nem is jön — vissza a mozdulatlan, ill. mozdulatlanná tevő tél.” A „körpálya mozdíthatatlannak látszó” dermesztő vége „fel fog engedni”, ${ }^{4}$ folytatódik a körforgás.

$\mathrm{Az}$ univerzum körforgása örökös, ott nincs veszteség (nincs halál!), ott a megújító ismétlődés az állandó. Az emberi lét megszúnte, ,alászállása” után: por és árnyék(világ) a lét, de ezzel már itt, e földi világban is szembe kell néznünk:

\section{Pulvis et umbra sumus.}

Jelen idő! Pedig azt várnánk, hogy porrá „leszünk” (erimus). Létünkben hordjuk az elmúlást. E világból költözünk abba az árnyvilágba, amelyben már itt, a jelenben élünk. Árnyvilág — árnylét!

Gondoljunk csak Kölcseyre! Őt is mennyire foglalkoztatta — akárcsak gondolkodó elődeit és utódait — az örök körforgás:

\section{„Kezdet és vég egymást éri”}

(Vanitatum vanitas)

Horatius - Kölcsey — Babits? Menjünk vissza időben! „Mert közös a kezdet és a

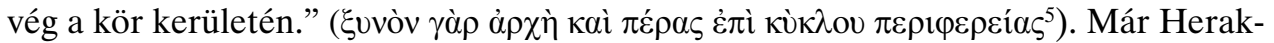

\footnotetext{
${ }^{2}$ Borzsák István: Horatius: Ódák és epódoszok. Budapest 1975. 459.

${ }^{3}$ Borzsák István: i. h.

${ }^{4}$ Borzsák István: i. h.

${ }^{5}$ H. Diels-W. Kranz: Die Fragmente der Vorsokratiker. I'. Berlin 1934. 174 (103. frg.).
} 
leitos töredékeiben olvashatjuk szinte szó szerint Kölcsey „gondolatait”, aki tovább gondolkodik a halhatatlanságról emlékbeszédében, amelyet az általa megbántott költő - Berzsenyi Dániel — búcsúztatásán mond el: „Az emberi nem, egészében tekintve, örökre virágzó növény, minek egyfelól hervadó virágai mellett, másfelól szünet nélkül újabb és újabbak fakadnak s nyílnak ki.” Idézzük fel a híres mondatot, amellyel így „engeszteli ki” a megbántott, halott Berzsenyit:

\section{„Árnyéka az elköltözöttnek, sírod felett zeng az engeszteló szózat.”}

Majd kérdez Kölcsey: „A megholtak jövendője hol vagyon? Kettő a felelet. Egy, mely a hit vezérkaraira utasít ... Más, mely az emberiség egésze felé fordul, s innen a síron, az enyészet nyomain mindig újonnan keletkezó életre figyelmeztet. Lelket emelő nagy gondolat fekszik mindegyikben!” Érezzük, hogy Kölcsey „engesztelő ajándék"-ával Berzsenyinek is megjósolja a halhatatlanságot. Mi mást tett Horatius? Már kilenc évvel e versének írása előtt ódakötetének záró ódájában (Carm. III. 30) ugyanezt jósolta magának (Kr. e. 23-ban):

\section{Non omnis moriar}

Kölcsey is, Babits is tudják, hogy halhatatlanok lesznek, hisz a világegyetem részei ók is.

E látszólagos kitérô után nézzük tovább Horatius versét: ha eltávozunk innen, az Alvilág uráé a rendelkezés, a rendezés joga. Ott nem ér semmit sem a származás, sem az ékes beszéd, de a pietas sem. Horatius ezt a fontos figyelmeztetést látszólag Torquatus nevú ismerősének címzi, ő a vers végének megszólítottja. A pietas Torquatus személyéhez nehezen kapcsolható, az ékes szó igen, hisz ügyvédként a „beszéd” volt a kenyere. A pietas, e nehezen meghatározható erkölcsi eszmény az a magatartásforma, amelyben a segító, „kegyes”, óvó tiszteletadásnak mellőzhetetlen szerepe van a szülók vagy az arra érdemes személyek iránt tanúsított viselkedésmódokban. Horatius korának princepse - Augustus - sajátjának tekintette a pietas erényét is. E fogalom elemzése Augustusszal kapcsolatban nehezen illeszthető ennek az írásnak a témájába, de mivel szerepel a versben, nem hagyhatjuk figyelmen kívül. Szép érzelmi töltésû szó. A baj csak az, hogy Augustus erénykatalógusába nehezen eröltethetô bele. A princeps ugyanis hatalma teljében olykor megfeledkezik arról, mivel tartozik barátainak, segítőinek. Mire megérne benne a „búnbánat”, hirtelen távozik ő is az életből, akárcsak „barátai”.

Horatius a baráti érzés mellőzhetetlen fontosságát úgy hangsúlyozza e versében, hogy az a két sor külön tanulmányt érdemel. Lényege: csak azt nem veheti el a kapzsi örökös bárkitől, amit lélekkel ad vagy lelkéből, lelkével ajándékoz barátjának. Horatius ajándékozott minden elveszejtett társának, életükben őszinteséget, haláluk után éltetô, emlékezô, halhatatlanságot nyújtó verseket. Ezzel szemben ódáinak záró, negyedik könyvét Augustusnak kifejezett óhajára írta. E vers érdekessége, hogy 
éppen a középsố ódája a 15 költeményből álló negyedik könyvnek, s ez arra mutat, hogy igen fontos a mondanivalója. Így érthető meg, hogy a pietas kiszól a versből. Torquatushoz nem kapcsolható, de Augustushoz sem. A pietas szó Horatiusnál egyébként összesen négyszer fordul eló életmúvében, de úgy, hogy minden ódakönyvben csak egyszer, tehát 103 versből csak négyben szerepel, akkor sem Augustusra vonatkoztatva. A Carmen saeculare híres himnuszában egyáltalán nem szerepel, ez is jelzésértékú Horatius Augustusról alkotott ítéletével kapcsolatban.

A pietas tehát nem véd az Alvilág hatalmától. Kérdés: kit? Torquatust? Aligha! Horatius szokott rejtjelezésével úgy építette fel e csodálatos optimista versét, hogy kijelenti:

\section{Immortalia ne speres}

Ezt magára természetesen nem vonatkoztathatja, hiszen a Carm. III. 30-ban már visszavonhatatlanul leírta:

és

\section{Non omnis moriar}

\section{Exegi monumentum}

Megalkotta azt a múvet, amely halhatatlanná teszi. Így teljesen kizárt, hogy Kr. e. 14 táján „őszikéinek” fájóan szép és elgondolkodtatóan rejtélyes versében magától vagy Torquatustól vonná meg a halhatatlanságot.

A lényeg az: valakinek nem jár az öröklét, a „szép halhatatlanság”. Ezután következik az örökéletû évszakok leírása, majd hirtelen feltúnik — pontosan a vers középpontjában - az Alvilág képe, ahol pius/pater Aeneas is meglelte helyét. Ezek után leszögezi Horatius, hogy a pietas sem segítene ott. Így csak összegezni kell Horatius jeladásait: „Te (valaki!) ne remélj halhatatlanságot pietas-od révén”. Hogyan mondhatta volna meg ezt nyíltan a költő a princepsnek, akinek tetteit éppen az ódáknak ebben a IV. könyvében kellett megénekelnie és magasztalnia. Erre Horatius ezt a tóle megszokott rejtjelezési módot választotta.

A princeps hihetőleg mégis megértette a nehezen érthető célzást, de azért hat évet még kapott ajándékba Horatius. Így értelmezve a verset, nem kelt félelmet bennünk. Ha a testi részt el is viszi az Alvilág, a szellem túléli az elmúlást. Halhatatlanul ott van az örök körforgásban, múlhatatlanul örök, mint a nagy egész. Mindazok, akik a pietas birtokában élték életüket, hírük, nevük, tisztességük révén számíthatnak a hallhatatlanságra.

\section{„Csak az én halálom nem halandó”}

— írja Babits, ahogyan Horatiusé sem az. Horatius őshite az öröklétben így olvasható ki a versből. A horatiusi vers gondolatai is azt sugallják, amit a babitsi sorok: az ô és övéi(k) halála „nem halandó”. 
Az évszakok körforgását Horatius olyan zenei-festói varázslattal tárja elénk, mint Vivaldi tette ezt zenéjével és a hozzá írott szonettjeivel, amelyek erősítik a zenei közlést. Ha ezt itt most nem is tudjuk hallhatóvá tenni, legalább olvassuk Vivaldi versét a Tél-tételhez:

„Fekete felhókből jönnek keményen a szörny szelek s szigorúan morognak. A percek lépte koppanó az éjben. A végtelen fagy fogakat vacogtat.

Vonulását az egykedvú napoknak tû́z mellől nézzük. Kint esôverésben járkál az élet, dermesztő fagyok vad világában bolyong reszketve tétlen.

Sokan csúszkálnak, olykor földre esnek, majd felszökve suhannak sima jégen. Még betörik páncélja a vizeknek.

Nagy vaskapuk mögül kitör merészen bóra, sirokkó, ura vad szeleknek. Ilyen a tél s mennyi öröm a télben.”

(Ford. Baranyi Ferenc)

A tél minden kellékével tél, fagyos és tétlen (iners!), de mind a zenében, mind a versben ott a feloldódás (olvadás!), a fortissimók bizonyosságát adják annak, hogy lesz folytatás, lesz tavasz.

Babitsnál a tél a halhatatlanság évszaka. Ha van halhatatlanság, tél, akkor van tavasz is, még ha Babits a két melengető évszakról nem is ír külön. A Tél-kezdetben van a legtöbb remény, amikor - ha lépésenként is — de kezd növekedni a fény. Horatius talán edzettebb lelkületú, mint Babits. Optimizmusuk nem harsogó, de azt mindketten tudják, hogy az elmúlásnak nem velejárója az elpusztulás, az elpusztító felejtés. Horatius és Babits halhatatlanságba vetett hite különböző költői képekben jut kifejezésre, de a végeredmény azonos. Egyikük halála sem „halandó”, de nem halandó az igaz úton járóké sem.

\section{SUMMARY}

Both the ode of Horace and the poem of Babits represent some „summary of life" in the creative existence of the two poets. Apparently, the tone of the poems is resigned. In reality, however, powerful affirmation of life is radiating towards us from these poetic verses, vigorously enabling us to see. This strength, coming from inside, and this belief in eternity is strengthened by the impressive music of 
Vivaldi, from which the sentiment of immortality, assured by the eternal rotation, is speaking to us by the language of music and poetry. Ode 7, inserted in the middle of Book IV of Horace, presents two millennia from the „eternity” while Babits speaks from the recent past, but the accord of the verses and the creative life assure the immortality for both and together with them for all those, who as active men of the cosmos are living according to its faultless laws so that they attache to the „minute life" the certainty, revealed by Madách, of the „sense of infinite”.

\section{FÜGGELÉK}

\section{RIMÓCZI-HAMAR MÁRTA}

\section{AZ ÉVSZAKOK KÖRFORGÁSÁNAK ASZTROLÓGIAI VONATKOZÁSAI}

Az évszakok körforgásának képzete Horatiusnál szorosan összefügg az évszakok változásának asztrológiai hátterével. Érdemes F. Cumontnak és R. Ghirshmannak abból a megállapításából kiindulnunk, amely szerint a János Jelenések könyvében leírt égi trónus négy alakjával s az égi királyként ábrázolt Krisztusnak ugyanettól a négy alaktól körülvett trónusa - mint ez a franciaországi Moissac templomának tympanonján látható ${ }^{1}$ - a perzsa királyi trónusra megy vissza. ${ }^{2}$ Mivel pedig a perzsa királyok az uralkodói képzetek szerint világuralkodók voltak, trónusuk a világot jelképezte s szimbolikájában is ez a képzet jutott kifejezésre. Így az égi trónus négy alakjában a zódiakus négy csillagképét kell látnunk. Ezek pedig a következők: Oroszlán (kezdete július 23.), Bika (kezdete április 21.), Emberarcú (= Vízöntó, kezdete január 20.), Sas (= Skorpió, alternatív elnevezés, kezdete október 23.). Hogy éppen ezek a zódiakus jegyek kaptak szerepet mind a perzsa trónus felépítésében, mind pedig annak apokaliptikus utódjánál, annak az volt az oka, hogy szerepük hangsúlyozottabb volt, mint az évszakok kezdetét jelző csillagképeknek. Vagyis a tavasz legdúsabb a Bika jegyében, azaz már „eltiporja” a nyár, a nyár a maga „interi-tura” állapotában még fellángol az Oroszlán jegyében, hogy innen azután már leáldozóban legyen és átadja helyét a frugifer autumnus-nak, az ösznek, amely úgy ontja elénk kincseit búcsúzóul, mint talán egyik évszak sem. Ekkor kezd halványulni az ôsz úgy, hogy a Skorpió jegyében (okt. 23.—nov. 21.) lecsendesüljön, elpihenjen és készüljön átadni helyét a bruma iners-nek, a télnek, amely elmélyedésre, összegzésre késztet. Szép csend van kívül - belül. Majd ez is elmúlik úgy, hogy a Vizöntố kezdi meg alig észlelhetô készülődését a tavaszra, amelyet újra eltipor a nyár, újra éled a bika és így ismétlődik a körforgás tovább.

\footnotetext{
${ }^{1}$ R. Ghirshman: Iran. Parthes et Sassanides. Paris 1962. 403. kép.

${ }^{2}$ R. Ghirshman: i. m. 304 sk.
} 
A csillagképek funkciója e körforgásban következőképpen ábrázolható:

$\begin{array}{ccc}\begin{array}{c}\text { kardinális, } \\ \text { évszakkezdố jegyek }\end{array} & \begin{array}{c}\text { állandó } \\ \text { évszakközépi jegyek }\end{array} & \begin{array}{c}\text { változó, } \\ \text { leáldozó jegyek }\end{array} \\ \text { Kos } & \text { Bika } & \text { Ikrek } \\ \text { Rák } & \text { Oroszlán } & \text { Szúz } \\ \text { Mérleg } & \text { Skorpió } & \text { Nyilas } \\ \text { Bak } & \text { Vízöntő } & \text { Halak }\end{array}$

A perzsa vallásos világképben az évszakok közepét szimbolizáló csillagképek csoportja királyi csillagképként volt ismeretes. ${ }^{3}$ Így még érthetôbbé válik a királyi hatalmat szimbolizáló uralkodói trónus csillagkép szimbolikája, amely a király tevékenységének sikeres kiteljesítéséhez a csillagképek örök körforgását s ezzel együtt az állandóságot biztosító természeti alapot adja. 